\title{
Sperm morphometry and chromatin condensation in Nelore bulls of different ages and their effects on IVF
}

\section{B.H. Kipper ${ }^{\text {a, } 1}$, J.T. Trevizan ${ }^{\text {a }}$, J.T. Carreira ${ }^{\text {b }}$, I.R. Carvalho ${ }^{\text {a }}$, G.Z. Mingoti ${ }^{\text {, }}$, M.E. Beletti ${ }^{\text {d, S.H.V. Perri }}{ }^{\text {c }}$, D.A. Franciscato ${ }^{\text {a }}$, J.C. Pierucci ${ }^{\text {, }}$,} M. B Koivisto ${ }^{\mathrm{a}, *}$

\footnotetext{
a Department of Medicine, Surgery and Animal Reproduction, Univ Estadual Paulista (UNESP), Araçatuba, São Paulo, Brazil

${ }^{\mathrm{b}}$ Department of Animal Reproduction and Obstetrics, University of Rio Preto (UNIRP), São José do Rio Preto, São Paulo, Brazil

${ }^{c}$ Department of Support, Production and Animal Health, Univ Estadual Paulista (UNESP), Araçatuba, São Paulo, Brazil

${ }^{\mathrm{d}}$ Laboratory of Histology, Federal University of Uberlândia (UFU), Uberlândia, Minas Gerais, Brazil

${ }^{\mathrm{e}}$ Department of Preventive Veterinarian Medicine and Animal Reproduction, Univ Estadual Paulista (UNESP), Araçatuba, São Paulo, Brazil
}

\section{A R T I C L E I}

\section{Article history:}

Received 26 February 2016

Received in revised form 16 August 2016

Accepted 17 August 2016

\section{Keywords:}

Toluidine blue

Bovine

Chromomycin A3

Fertility

Semen

\begin{abstract}
A B S T R A C T
The aim of this study was to evaluate the chromatin packing and sperm head morphometry of cryopreserved semen of Nelore bulls (Bos taurus indicus) of different ages. Furthermore, the influence of the degree of chromatin compaction on in vitro embryo production (IVP) was investigated. Forty bulls were divided into three groups: young (1.82 years), adult (3.5-7 years), and senile ( $8-14.3$ years). The ejaculates were frozen according to standards established by the Artificial Insemination Center located in the Southeast of Brazil. Toluidine blue staining was used for simultaneous evaluation of the sperm chromatin and sperm head morphometry. Chromomycin A3 (CMA3) was applied to analyze sperm protamination and IVP for embryonic development. Spermatozoa of young bulls presented higher values for area ( $A$, pixels), perimeter ( $\mathrm{P}$, pixels), and width (W, pixels) compared to adults and senile (young: $\mathrm{A}=1848.5 \pm 119.79, \mathrm{P}=10.23 \pm 0.29$, and $\mathrm{W}=1.95 \pm 0.1$; adults: $\mathrm{A}=1672.9 \pm 104.46, \mathrm{P}=9.86 \pm 0.33$, and $\mathrm{W}=1.81 \pm 0.06$; senile: $\mathrm{A}=1723.1 \pm 124.41, \mathrm{P}=9.97 \pm 0.33$, and $\mathrm{W}=1.83 \pm 0.09 ; \mathrm{P}<0.0001)$ and showed higher protamination deficiency when analyzed by CMA3 (young: $1.57 \pm 0.76$; adults: $1.09 \pm 0.63$, and senile: $0.90 \pm 0.59 ; \mathrm{P}<0.05)$. Likewise, variables of sperm head size $(\mathrm{A}, \mathrm{P}$, and $\mathrm{W})$ and protamination assessed by CMA3 showed negative correlation with age and positive correlation with ellipticity, evaluated by toluidine blue method $(\mathrm{P}<0.05)$. Sperm head area was larger in spermatozoa presenting chromatin instabilities than spermatozoa without chromatin alteration $(\mathrm{P}<0.0001)$. There was no difference in IVP when using semen with larger or smaller portions of spermatozoa with chromatin instabilities, indicating that the proportion of sperm with abnormal chromatin compaction (4\%-16.15\%) did not interfere with early embryonic development. From our results, it can be concluded that sperm of young Nelore bulls have larger heads compared to adults and senile due to reduced protamine content when evaluated by CMA3 and higher proportion of major sperm defects assessed by differential interference contrast microscopy.
\end{abstract}

(C) 2016 Published by Elsevier Inc.

\footnotetext{
* Corresponding author. Tel.: 00551836361400.

E-mail address: koivisto@fmva.unsep.br (M.B. Koivisto).

${ }^{1}$ Present Address: Veterinary Medicine Department, Fundação Universidade Regional de Blumenau (FURB), Blumenau, Brazil.
} 


\section{Introduction}

Embryonic mortality in cattle is pointed out as the main source of economic loss for livestock producers [1]. Embryo survival is a major factor affecting production and economic efficiency in all systems of ruminant milk and meat production. In Brazil, the embryonic mortality in cattle leads to a loss of 350 to 850 million US\$/year [2]. Semen analysis, a primary method of fertility diagnosis, evaluates sperm count, motility, morphology, plasma membrane, and acrosomal membrane integrity. However, modifications in sperm chromatin are usually not taken into account [3]. Spermatozoa containing chromatin instabilities are able to fertilize oocytes both in vivo and in vitro; however, the defect may persist throughout the embryonic period, inducing apoptosis, embryonic disruption, and abortion [4,5].

Previous to meiosis, the chromatin in the spermatocyte nucleus is diffusely organized similarly to the nucleus of all somatic cells. The predominant proteins in this phase are histones, which increase their volume [6,7]. When spermiogenesis is initiated, protamines become most abundant in mammalian sperm nucleus and allow high organization, condensation, and compaction [8,9].

The head of mammalian spermatozoa consists almost entirely of chromatin. In case of changes in chromatin structure, morphologic abnormalities are expected [3,10,11]. However, some studies have shown that sperm containing abnormal chromatin condensation do not necessarily present morphologic changes, requiring morphologic analysis followed by evaluation of the internal structure [12,13].

Recent studies regarding the compaction of chromatin related to sperm head morphometry in cattle do not compare different age groups [11,14-16]. The aim of this study was to investigate the relationship between chromatin condensation and sperm morphometry in young, adult, and senile Nelore bulls and its influence on fertility.

\section{Material and methods}

\subsection{Animals and experimental design}

A total of 40 healthy Nelore bulls, kept on native pasture (Cynodon plectostachyus) with dietary supplementation to fulfill energy balance, were selected from an Artificial Insemination Center located in Southeastern Brazil $\left(21^{\circ} 09^{\prime} 56.58^{\prime \prime} \mathrm{S} / 048^{\circ} 02^{\prime} 25.13^{\prime \prime} \mathrm{W}\right)$. The ejaculates were obtained by artificial vagina, routinely tested and classified as normospermia and frozen in $0.25-\mathrm{mL}$ straws according to standard procedures established by Artificial Insemination Center and stored in liquid nitrogen until evaluation. Three groups of bulls were evaluated, with three ejaculates per animal: young group (from 1.8- to 2-years old, $\mathrm{n}=9$ ), adult group (from 3.5- to 7-years old, $\mathrm{n}=19$ ), and senile group (from 8- to 14.3-years old, $\mathrm{n}=12$ ). All evaluations in this study were performed with cryopreserved semen samples.

\subsection{Semen evaluation}

\subsubsection{Conventional physical tests}

Semen thawing was performed at $35^{\circ} \mathrm{C}$ for 20 seconds. Postthaw semen evaluation included progressively motile spermatozoa (\%), sperm concentration (Neubauer chamber), and spermatozoa with morphologic abnormalities (\%, differential interference contrast microscopy [Olympus BX61] in a humid chamber, $\times$ 1000) [17].

Three ejaculates were collected from each bull using an artificial vagina according to a regular twice-a-week collection schedule and evaluated according to standard procedures for volume $(\mathrm{mL})$, sperm concentration $\left(10^{6} / \mathrm{mL}\right.$, photometry), gross motility (zero to five), progressively motile spermatozoa (\%) (subjective estimation using phase contrast microscopy, $\times 200$ ), and spermatozoa with morphologic defects. For evaluation of sperm morphology, spermatozoa were fixed in a stock solution of buffered formol saline [18]. Sperm alterations were classified into major defects (i.e., primary acrosome defects, proximal droplets, abnormal loose heads, abnormal head contour, abnormal midpiece, nuclear vacuoles, double forms, and dag defect) and minor defects, a total of 200 cells were examined per sample $[19,20]$.

\subsubsection{Sperm head morphometry and chromatin condensation evaluation with toluidine blue}

Gray-level digital images of a minimum of 100 spermatozoa per smear were obtained (light microscopy, Olympus BX 61 coupled to an DP-71 Olympus camera, $\times 100$ magnification), and the average intensities of the gray-levels per head in each image were determined using software programs developed in the SCILAB environment, according to the protocol established by Beletti and Costa [21].

The reference for the normal spermatozoa staining was performed by an automatic selection of six heads in each smear and considering the mean value of the pixel values of these heads. Heads presenting the highest average pixel values and homogeneousness were selected. Next, for each image, the difference between the average value of standard heads and the value of each head examined was determined. Finally, the coefficient of variation (\%) of gray level and the percentage difference in the degree of ash (\% diff) was calculated. Sperm heads with difference greater than $2.0 \%$ and/or gray level to the degree of ash greater than 5.0 were considered to have abnormal chromatin structure [22].

Morphometric variables evaluated by this technique by programs developed in SCILAB were area $(A)$, perimeter $(P)$, width (W), length (L), length/width ratio (L/W), ellipticity (E), shape factor (SF), Fourier descriptors with amplitude of zero to two (F0, F1, and F2), lateral symmetry (LS), and anteroposterior symmetry (APS) [21].

$\mathrm{A}, \mathrm{P}, \mathrm{W}$, and $\mathrm{L}$ have become standard measures; L/W and E are derived from the previous basic measures. Ellipticity is described as measure of elongation of the head contour, normalized such that $-1<$ and $<1$. SF is obtained from the basic measures and indicates the deviation of the head contour from smooth ellipse [21].

\subsubsection{Evaluation of sperm protamination with chromomycin A3 (CMA3)}

For evaluation of sperm protamination, the CMA3 fluorescent dye (Sigma, St. Louis, MO, USA) was used. The staining protocol for flow cytometry has been developed 
according to Tavalaee et al. [23], and for the positive control, the protocol described by Simoes et al. [24] was used, which consists in induction of disulfide bonds cleavage between the protamine chains and permeabilization of the plasma membrane of sperm samples.

After staining, the reading was performed by flow cytometry, 10,000 events, per sample, corresponding to sperm, were stimulated by 488-nm argon laser and read in the blue laser (BL1) filter (530/30 nm).

\subsubsection{In vitro embryo production (IVP)}

Ovaries from slaughtered cows were obtained in a local abattoir and transported to the laboratory. Intact cumulusoocyte complexes (COCs) were aspirated from antral follicles (3-8 $\mathrm{mm}$ in diameter), and oocytes with at least four layers of cumulus cells with homogenous cytoplasm were selected for the experiments. Selected COCs were washed and cultured in 100- $\mu \mathrm{L}$ droplets of IVM medium (20-25 oocytes per droplet), which consisted of TCM-199 (GIBCO BRL Invitrogen, Grand Island, NY, USA) supplemented with $10 \%(\mathrm{v} / \mathrm{v}$ ) fetal calf serum (GIBCO BRL Invitrogen), 0.2-mM sodium pyruvate, 25-mM sodium bicarbonate, $50-\mu \mathrm{g} \mathrm{mL}^{-1}$ amikacin, 0.5- $\mu \mathrm{g} \mathrm{mL}^{-1} \mathrm{FSH}$ (Folltropin-V; Bioniche Animal Health, Lavaltrie, Canada), and $100-\mathrm{IU} \mathrm{mL}^{-1}$ hCG (Vetecor; Hertape Calier, Juatuba, Brazil). Cumulusoocyte complexes were cultured under mineral oil, for 22 hours at $38.5{ }^{\circ} \mathrm{C}$ under an atmosphere of $5 \% \mathrm{CO}_{2}$ in air with maximum humidity.

Matured oocytes were subjected to IVF with pooled semen of three Nelore bulls (Bos taurus indicus) showing 4\% to $16.15 \%$ of alterations in sperm chromatin compactation (CD group-with chromatin damage) and three Nelore bulls without alterations in chromatin compaction (WCD group-without chromatin damage). The bulls were chosen based on the results from sperm chromatin evaluation by toluidine blue technique. Pool of three different individuals per group was used to eliminate the bull effect, as the male factor is widely known to influence IVF outcome [25]. For the control group we used, semen from a single Nelore bull of proven fertility was routinely used in our laboratory [26].

Motile spermatozoa were obtained by centrifuging thawed semen twice at $300 \times g$ for 5 minutes at room temperature in Tyrode's albumin lactate pyruvate [27] containing $0.2-\mathrm{mM}$ Na-pyruvate, $6-\mathrm{mg} \mathrm{mL}^{-1}$ fatty acid-free bovine serum albumin, 25-mM sodium bicarbonate, 13-mM Na lactate, $50-\mu \mathrm{g} \mathrm{mL}^{-1}$ amikacin. Spermatozoa $\left(100 \times 10^{3}\right.$ cells $\left.\mathrm{mL}^{-1}\right)$ were added to the fertilization droplet containing $90-\mu \mathrm{L}$ fertilization medium, which consisted of Tyrode's albumin lactate pyruvate supplemented with $40-\mu \mathrm{L} \mathrm{mL}{ }^{-1}$ PHE solution (final concentrations of $20-\mu \mathrm{M}$ penicillamine, $10-\mu \mathrm{M}$ hypotaurine, and $2-\mu \mathrm{M}$ epinephrine) and $10-\mu \mathrm{g} \mathrm{mL}^{-1}$ heparin. The COCs (20-25 per droplet) and spermatozoa were coincubated for 18 hours at $38.5{ }^{\circ} \mathrm{C}$ in an atmosphere of $5 \% \mathrm{CO}_{2}$ in air, with maximum humidity. The day of fertilization was defined as Day 0 .

Following IVF, the presumptive zygotes (20-25 oocytes per droplet) were stripped from the cumulus cells by vortexing and transferred to $100-\mu \mathrm{L}$ droplets of modified synthetic oviductal fluid [28] supplemented with $50-\mu \mathrm{g} \mathrm{mL}$ amikacin, $5 \mathrm{mg} \mathrm{mL}^{-1}$ fatty acid-free bovine serum albumin, and $2.5 \%(\mathrm{v} / \mathrm{v})$ fetal calf serum, under mineral oil at $38.5^{\circ} \mathrm{C}$ in an atmosphere of $5 \% \mathrm{CO}_{2}$ in air, with maximum humidity. Cleavage rates were assessed under stereoscopic microscopy at $\times 40$ magnification 72 hours post insemination (h.p.i.; Day 3 ), and blastocyst development rates were recorded at 168 h.p.i. (Day 7) and at 192 h.p.i. (Day 8).

\subsubsection{Statistical analysis}

To investigate the differences in the variables sperm motility, concentration, morphology, variables analyzed by toluidine blue and CMA3 and IVP, analysis of variance (ANOVA) was carried out and the means were compared by Tukey's test. Data in percentage (blastocyst formation rates at Day 7 and Day 8 ) were transformed into arcsine $\sqrt{\%}$ to obtain the normal distribution and perform analysis of variance. The Spearman correlation coefficient $(r)$ was calculated for the selected variables. The significance of the tests was determined for $P$ values less than 0.05 , and analysis were performed with SAS (Statistical Analysis System, SAS Institute, Cary, NC, USA, 2008) version 9.2.

\section{Results}

Table 1 summarizes the postthaw semen characteristics, morphometric and chromatin values according to the age range. Spermatozoa of young and adult bulls showed higher values of motility compared to senile. Sperm concentration and major sperm defects were higher in young bulls.

Spermatozoa of young bulls showed higher values of area, perimeter, and width and lower ellipsoid portion than adult and senile bulls. The degree of compaction of chromatin did not differ significantly among groups when assessed by toluidine blue stain. However, the percentage of spermatozoa with abnormal chromatin, defined as percentage of sperm heads with chromatin decompaction rate greater than 2.0 and/or chromatin heterogeneity greater than 5.0 , varied from $0 \%$ to $16.15 \%$. Flow cytometric evaluation of sperm protamination with CMA3 revealed stronger protamination deficiency in sperm heads of young bulls compared with older bulls (Table 1 ).

Variables of sperm head size (A, P, W) and protamination assessed by CMA3 showed negative significant correlation with age $(\mathrm{r}=-0.272 ;-0.241 ;-0.288$; and -0.335 , r), respectively and positive significant correlation with ellipticity $(0.272, \mathrm{r})$, evaluated by toluidine blue method $(\mathrm{P}<0.05)$.

In spermatozoa showing abnormalities in chromatin structure, the area of the head was significantly larger than that in spermatozoa with normal chromatin structure (Table 2).

Cleavage rates $(76.58 \pm 4.84 \%$ to $81.09 \pm 9.79 \%)$ and embryo development to the blastocyst stage at Day 7 (36.73 $\pm 19.72 \%$ to $49.74 \pm 30.58 \%)$ and Day 8 (37.84 $\pm 21.35 \%$ to $48.15 \pm 28.04 \%$ ) were unaffected $(\mathrm{P}>0.05)$ by chromatin damage in sperm cells (Table 3 ).

\section{Discussion}

This study shows a clear relationship between compaction of chromatin and sperm head morphometry. 
Table 1

Mean $(\bar{x})$ and standard deviation ( \pm SD) of motility, concentration, major, minor, and total sperm defects, morphometric variables of the sperm head, chromatin decompaction, and instability of chromatin evaluated by toluidine blue and percentage of spermatozoa with chromatin alteration evaluated by CMA3 staining of young $(\mathrm{N}=27, \mathrm{H}=7629)$, adult $(\mathrm{N}=59, \mathrm{H}=15186)$, and senile $(\mathrm{N}=36, \mathrm{H}=8966)$ Bos taurus indicus Nelore bulls.

\begin{tabular}{|c|c|c|c|}
\hline Parameters & Young $(\bar{x} \pm \mathrm{SD})$ & Adult $(\bar{x} \pm \mathrm{SD})$ & Senile $(\bar{x} \pm$ SD) \\
\hline Motility (\%) & $38.9 \pm 10.9^{\mathrm{a}}$ & $38.2 \pm 8.8^{\mathrm{ab}}$ & $33.7 \pm 6.1^{\mathrm{b}}$ \\
\hline Sperm concentration $\left(\times 10^{6}\right.$ spermatozoa $)$ & $28.6 \pm 8.7^{\mathrm{a}}$ & $21.0 \pm 3.3^{c}$ & $24.5 \pm 4.7^{b}$ \\
\hline Major sperm abnormalities (\%) & $13.7 \pm 5.0^{\mathrm{a}}$ & $9.3 \pm 5.7^{b}$ & $9.2 \pm 4.7^{\mathrm{b}}$ \\
\hline Minor sperm abnormalities (\%) & $5.1 \pm 3.3$ & $6.3 \pm 3.9$ & $6.3 \pm 5.0$ \\
\hline Total sperm abnormalities (\%) & $18.8 \pm 7.0$ & $14.5 \pm 7.8$ & $15.1 \pm 6.4$ \\
\hline Area (pixels) & $1848.5 \pm 119.79^{a}$ & $1672.9 \pm 104.46^{\mathrm{b}}$ & $1723.1 \pm 124.41^{\mathrm{b}}$ \\
\hline Perimeter (pixels) & $10.23 \pm 0.29^{\mathrm{a}}$ & $9.86 \pm 0.33^{\mathrm{b}}$ & $9.97 \pm 0.33^{\mathrm{b}}$ \\
\hline Width (pixels) & $1.95 \pm 0.1^{\mathrm{a}}$ & $1.81 \pm 0.061^{\mathrm{b}}$ & $1.83 \pm 0.09^{b}$ \\
\hline Length (pixels) & $3.89 \pm 0.11$ & $3.81 \pm 0.14$ & $3.86 \pm 0.13$ \\
\hline Width/length & $0.5 \pm 0.03^{\mathrm{a}}$ & $0.48 \pm 0.02^{\mathrm{b}}$ & $0.47 \pm 0.02^{\mathrm{b}}$ \\
\hline Elliptical shape & $0.33 \pm 0.02^{\mathrm{a}}$ & $0.36 \pm 0.02^{b}$ & $0.36 \pm 0.02^{b}$ \\
\hline Shape factor & $0.92 \pm 0.02^{\mathrm{a}}$ & $0.91 \pm 0.01^{\mathrm{b}}$ & $0.9 \pm 0.01^{\mathrm{b}}$ \\
\hline Fourier 0 & $2784.9 \pm 212.01$ & $2751.4 \pm 272.4$ & $2810.0 \pm 2226.24$ \\
\hline Fourier 1 & $293.14 \pm 59.94$ & $281.32 \pm 44.88$ & $274.62 \pm 50.6$ \\
\hline Fourier 2 & $200.07 \pm 17.53^{\mathrm{a}}$ & $181.64 \pm 14.56^{\mathrm{b}}$ & $186.24 \pm 19.42^{\mathrm{b}}$ \\
\hline Lateral symmetry & $0.961 \pm 0.005^{\mathrm{a}}$ & $0.958 \pm 0.003^{\mathrm{b}}$ & $0.958 \pm 0.004^{\mathrm{b}}$ \\
\hline Anteroposterior symmetry & $0.93 \pm 0.01$ & $0.93 \pm 0.01$ & $0.93 \pm 0.01$ \\
\hline Chromatin decompaction (\%) & $1.13 \pm 0.22$ & $1.06 \pm 0.34$ & $1.04 \pm 0.29$ \\
\hline Instability of chromatin (\%) & $0.91 \pm 0.17$ & $0.83 \pm 0.15$ & $0.86 \pm 0.15$ \\
\hline CMA3 & $1.57 \pm 0.76^{\mathrm{a}}$ & $1.09 \pm 0.63^{b}$ & $0.90 \pm 0.59^{b}$ \\
\hline
\end{tabular}

${ }^{\mathrm{a}, \mathrm{b}}$ Different letters in the line indicate significant differences by Tukey test $(\mathrm{P}<0.05)$.

Abbreviations: CMA3, Chromomycin A3; H, number of sperm heads; $\mathrm{N}$, number of evaluated ejaculates.

Young bulls presented larger sperm head area than both adult and senile bulls, possibly due to higher protamination deficiency index, as demonstrated by CMA3 staining, and higher values of major sperm defects. Nevertheless, $4 \%$ to $16.15 \%$ of spermatozoa with deficient chromatin compaction in the sample did not impair embryo development in IVP until Day 8.

Previous studies in Nelore bulls showed changes in semen quality after puberty characterized by increased motility and percentage of normal morphology in addition to a decrease of major sperm defects [29]. In another research, young bulls at mean ages of 13,18 , and 24 months showed an increase in the percentage of morphologic normal sperm with age progression [30]. Positive correlations between age and body and testicular growth or seminal physical aspects of the ejaculate were observed in Nelore bulls between 10 and 20 months showing an improvement in seminal characteristics with sexual maturity. In agreement with our study, sperm defects also decreased with age [31].

Our results indicate that young bulls had larger sperm head area than both adult and senile bulls. To our knowledge, there are no studies comparing these morphometric sperm parameters at different ages following sexual

Table 2

Mean $(\bar{x})$ and standard deviation $( \pm$ SD) of the spermatozoa head area with abnormal and normal chromatin structure.

\begin{tabular}{lrl}
\hline Group & H & Area (pixels); $(\bar{x} \pm \mathrm{SD})$ \\
\hline Abnormal chromatin & 650 & $2194.8 \pm 509.08^{\mathrm{a}}$ \\
Normal chromatin & 10,000 & $1792.1 \pm 324.28^{\mathrm{b}}$ \\
\hline
\end{tabular}

${ }_{\mathrm{a}, \mathrm{b}}$ Different letters in the column indicate significant differences $(\mathrm{P}<0.0001)$.

Abbreviation: $\mathrm{H}$, number of sperm heads. maturity in bulls. Similar results were shown in rams where all morphometric dimensions values decreased, except for length, with the increase of sexual maturity [32]. In rabbits, the highest values for width, area, and length were observed in males with 6 to 8 months of age that could be considered as mature rabbit males and sperm head dimensions were shown to be hereditable [33].

A study in roosters showed larger sperm head area in younger males due to increased morphological abnormalities [34]. In contrast, older boars showed spermatozoa with larger head area than their younger counterparts [35]. Fourier harmonic amplitude (FHA) 2 measures sperm length, indicating microcephalic and macrocephlic sperm [36] and this parameter was significantly increased in young bulls. The FHA assists in the identification of changes on sperm nuclear shape, and substantial variation in shape exists among sperm considered to be normal. It has been shown that bulls with reduced fertility have sperm nuclei showing longer length (FHA 2). Identification of decreased fertility in males is greater than 95\% using FHA data, thus allowing for the culling of bulls with reduced fertility, identified through this analysis, reducing financial losses [37].

Young bulls in the present study showed a higher percentage of spermatozoa with protamination deficiency, rated by CMA3, possibly due to reproductive immaturity. Similar results were observed in young rats when compared to older ones, undergoing the same evaluation by CMA3 [38]. Further, a study indicated a possible effect of age in protamine content in Bos indicus bulls where age was positively correlated with low CMA3 binding [39]. The authors also suggested an association between lower sperm protamine content and sperm DNA damage. However, another study did not find a correlation between age of bulls and sperm chromatin integrity following analysis 
Table 3

Effect of chromatin damage in sperm cells on cleavage rates and embryo development to the blastocyst stage.

\begin{tabular}{llll}
\hline Group & No of oocytes & \% Cleavage $(\bar{x} \pm$ SD $)$ & \% Blastocyst Day $7(\bar{x} \pm$ SD $)$ \\
\hline Control & 158 & $81.09 \pm 9.79$ & $49.74 \pm 30.58$ \\
CD & 158 & $78.76 \pm 9.24$ & $46.05 \pm 25.55$ \\
WCD & 164 & $76.58 \pm 4.84$ & $36.73 \pm 19.72$ \\
\hline
\end{tabular}

The data represent the mean $(\bar{x}) \pm$ standard deviation $( \pm \mathrm{SD})$. No differences were observed between treatments $(\mathrm{P}>0.05$, Tukey's test). Abbreviations: CD, sperm cells with chromatin damage; SD, standard deviation; WCD, sperm cells without chromatin damage.

by Sperm-bos-halomax and sperm chromatin structure assay [30]. This can be explained by the difference in age groups employed in the studies and also by the fact that we used highly selected animals from an Artificial Insemination Center.

We observed that spermatozoa with chromatin changes present macrocephaly when compared to those considered normal in regards to chromatin status and also a less elliptical shape to their heads. These results were similar in all age groups studied. It is known that condensation of sperm DNA, in addition to protecting the genetic material, determines the shape and size of the sperm cell $[6,7]$. Therefore sperm showing fragmented DNA are commonly associated with morphologic sperm abnormalities [11]. However, abnormalities in chromatin are not always accompanied by apparent morphologic changes, indicating the need of analyzing the sperm DNA regarding chromatin compaction, to improve the use of reproductive biotechnologies [11,22]. Previous study showed a high and positive correlation between primary sperm defects and chromatin alteration, suggesting that sperm chromatin structure affected sperm head morphology [3].

Spermatozoa with deficient chromatin compaction in the sample (up to 16.15\%) did not impair the initial development of in vitro produced embryos until Day 8 of culture. Data are in agreement with previous study by Fatehi et al. [40] who demonstrated that DNA damage in bovine sperm does not block fertilization and early embryonic development but induces apoptosis after the first cleavages. One hypothesis for this finding may the reduced number of spermatozoa with damaged chromatin in the sample or the short period analyzed, suggesting that further research to evaluate the relationship between DNA damage on pregnancy, abortion, and postnatal development is warranted. Nevertheless, up to the present date, there are no consistent data considering the effects of DNA damage on embryo development or pregnancy outcome [9].

In the present study, we used pooled semen of three different individuals per group aiming to remove the bull effect [25]. Available evidence suggests the existence of a bull effect on embryonic development that may not be related to sperm penetration rate or the apparent normality of fertilization [25,41-46]. In fact, a previous study from our group investigating cytoplasmic droplets in sperm cells, observed that the bull effect was more important to the embryo development than the defect itself [47]. For the purpose of IVP, an interesting alternative to avoid bull effect is to use pooled semen rather than semen from only one bull [48]. Our objective in the present work was to compare semen of bulls with chromatin damage with semen from healthy animals, regardless of different intensities of injury. So pooling the semen of different animals was employed to avoid the bull effect, to investigate chromatin damage.

Our current results shed light on physiological agerelated changes in sperm head dimensions and chromatin compaction and for optimization of fertility. The integrity of spermatozoal DNA is an important factor because defects in chromatin are incompatible with fertility [49] and is often not analyzed in routine semen analysis [50].

CMA3 results have shown that young bulls had higher percentages of spermatozoa with protamination deficiency, whereas no significant differences between age groups could be shown by toluidine blue staining. This may be explained by the fact that only a few sperm cells (100 cells/ sample) can be evaluated by the toluidine blue technique compared to CMA3 (10,000 cells/sample) by means of flow cytometry.

The finding that young bulls present larger sperm head dimensions, likely due to looser chromatin, implies that bulls of this age should be further tested in the procedure of selection of semen donors. The study highlights the importance of morphometric evaluation of sperm heads followed by DNA analysis in routine semen analysis. Since it was demonstrated that spermatozoa with less chromatin compaction are larger than those considered normal, the use of semen with a high amount of spermatozoa with increased sperm head size in reproduction biotechnologies should be avoided to minimize fertilization failure.

\subsection{Conclusions}

From our results, it can be concluded that spermatozoa of young Nelore bulls have larger head dimensions when compared to those of adult and senile bulls due to lower protamination levels, when evaluated by CMA3, and major abnormalities. Deficiencies in chromatin compaction appear to be associated to an increase in sperm head dimensions. However, when present up to a $16.15 \%$ level in the sample, this lesser compaction did not affect embryo development to Day 8 in an IVP system.

\section{Competing Interests}

The authors declare that there is no conflict of interest that could affect the impartiality of the reported research.

\section{Acknowledgments}

The authors thank Lúcia Helena Rodrigues for providing the samples, Bruno Augusto Nassif Travençolo for technical 
assistance, Nathália A. S. Rocha-Frigoni and Beatriz C. S. Leão for the kind assistance with the IVP procedures, and FAPESP for the financial support (2010/07599-7; 2012/ 10471-8). B.H. Kipper carried out the semen evaluation, IVF procedures, and wrote the manuscript; J.T. Trevizan, I.R. Carvalho, and D.A. Franciscato participated with semen evaluation; M.E. Beletti coordinated the toluidine blue procedure; G.Z. Mingoti coordinated the IVF procedure; S.H.V. Perri made the statistical analysis; J.C. Pierucci helped revising the manuscript, and $\mathrm{M}$. B. Koivisto was the organizer and the principal investigator. All the authors have read and approved the final manuscript.

\section{References}

[1] Zavy MT. Embryonic mortality in cattle. In: Zavy MT, Geisert RD, editors. Embryonic mortality in domestic species. Boca Raton: CRC Press; 1994. p. 99-140.

[2] Informa Economics. Anuário da Pecuária Brasileira. Eighteenth edition. São Paulo: Informa Economics FNP; 2011.

[3] Beletti ME, Mello MLS. Comparision between the toluidine blue stain and the Feulgen reaction for evaluation of rabbit sperm chromatin condensation and their relationship with sperm morphology. Theriogenology 2004;62:398-402.

[4] Ellington JE, Evenson DP, Fleming JE, Brisbois RS, Hiss GA, Broder SJ, et al. Coculture of human sperm with bovine oviduct epithelial cells decreases sperm chromatin structural changes seen during culture in media alone. Fertil Steril 1998;69:643-9.

[5] Twigg JP, Irvine DS, Aitken RJ. Oxidative damage to DNA in human spermatozoa does not preclude pronucleus formation at intracytoplasmic sperm injection. Hum Reprod 1998;13:1864-71.

[6] Balhorn R. Sperm chromatin: an overview. In: Zini A, Agarwal A, editors. Sperm chromatin: biological and clinical applications in male infertility and assisted reproduction. New York: Springer; 2011. p. 3-18.

[7] Sharma R, Agarwal A. Spermatogenesis: an overview. In: Zini A, Agarwal A, editors. Sperm chromatin: biological and clinical applications in male infertility and assisted reproduction. New York: Springer; 2011. p. 19-44.

[8] Ward WS, Coffey DS. DNA packaging and organization in mammalian spermatozoa: comparison with somatic cells. Biol Reprod 1991; 44:569-74.

[9] Zini A, Agarwal A. Sperm chromatin: biological and clinical applications in male infertility and assisted reproduction. First edition. New York: Springer; 2011.

[10] Ostermeier GC, Sargeant GA, Yandell BS, Evenson DP, Parrish JJ. Relationship of bull fertility to sperm nuclear shape. J Androl 2001; 22:595-603.

[11] Enciso M, Cisale H, Johnston SD, Sarasa J, Fernandez JL, Gosalvez J. Major morphological sperm abnormalities in the bull are related to sperm DNA damage. Theriogenology 2011;76:23-32.

[12] Beletti ME, Costa Lda F, Viana MP. A comparison of morphometric characteristics of sperm from fertile Bos taurus and Bos indicus bulls in Brazil. Anim Reprod Sci 2005;85:105-16.

[13] Soares JM, Beletti ME. Avaliação da integridade cromatínica de espermatozoides de galos (Gallus gallus, Linnaeus, 1758) de linhagem pesada de duas idades. Braz J Vet Res Anim Sci 2006;42: 543-53.

[14] Revay T, Nagy S, Kopp C, Flyckt A, Rens W, Rath D, et al. Macrocephaly in bull spermatozoa is associated with nuclear vacuoles, diploidy and alteration of chromatin condensation. Cytogenet Genome Res 2009;126:202-9.

[15] Oliveira LZ, Santos RM, Lima VFMH, Arruda RP, Andrade AFC, Guimarães Junior V, et al. Chromatin and morphometry alterations of bovine sperm head after Percoll ${ }^{\mathrm{tm}}$ density gradient centrifugation. Livest Sci 2011;141:267-71.

[16] Rahman MB, Vandaele L, Rijsselaere T, Maes D, Hoogewijs M Frijters A, et al. Scrotal insulation and its relationship to abnormal morphology, chromatin protamination and nuclear shape of spermatozoa in Holstein-Friesian and Belgian Blue bulls. Theriogenology 2011;76:1246-57.

[17] Colégio Brasileiro de Reprodução Animal. Manual para exame andrológico e avaliação de sêmen animal. Third edition. Belo Horizonte: CBRA; 2013. p. 104
[18] Hancock JL. The morphology of boar spermatozoa. J R Microsc Soc 1957;76:84-97.

[19] Blom E. Ultrastructure of some characteristic sperm defects and a proposal for a new classification of the bull spermiogram. Nord Vet Med 1973;25:383-91.

[20] Barth AD, Oko RJ. Abnormal morphology of bovine spermatozoa. Ames: Iowa State University Press; 1989.

[21] Beletti ME, Costa Lda F. A systematic approach to multispecies sperm morphometric characterization. Anal Quant Cytol Histol 2003;25:97-107.

[22] Beletti ME, Costa L da F, Guardieiro MM. Morphometric features and chromatin condensation abnormalities evaluated by toluidine blue staining in bull spermatozoa. Braz J Morphol Sci 2005; 22:85-90.

[23] Tavalaee M, Kiane A, Arbabian M, Deemeh MR, Esfahani MHN. Flow cytometry: a new approach for indirect assessment of sperm protamine deficiency. Intl J Fertil Sterili 2010;3:177-84.

[24] Simoes R, Feitosa WB, Mendes CM, Marques MG, Nicacio AC, de Barros FR, et al. Use of chromomycin A3 staining in bovine sperm cells for detection of protamine deficiency. Biotech Histochem 2009;84:79-83.

[25] Gordon I. Laboratory Production of Cattle Embryos. Second edition. Cambridge: CABI Publishing; 2003. p. 215-6.

[26] Rocha-Frigoni NAS, Leao BCS, Nogueira E, Accorsi MF, Mingoti GZ. Effects of gaseous atmosphere and antioxidants on the development and cryotolerance of bovine embryos at different periods of in vitro culture. Zygote 2015;23:159-68.

[27] Parrish JJ, Susko-Parrish J, Winer MA, First NL. Capacitation of bovine sperm by heparin. Biol Reprod 1988;38:1171-88.

[28] Vajta G, Rindom N, Peura TT, Holm P, Greve T, Callesen H. The effect of media, serum and temperature on in vitro survival of bovine blastocysts after open pulled straw (OPS) vitrification. Theriogenology 2009;52:939-48.

[29] Brito LFC, Silva AEDF, Unanian MM, Dode MAN, Barbosa RT, Kastelic JP. Sexual development in early- and late-maturing Bos indicus and Bos indicus $\times$ Bos taurus crossbred bulls in Brazil. Theriogenology 2004;62:1198-217.

[30] Fortes MRS, Holroyd RG, Reverter A, Venus BK, Satake N, BoeHansen GB. The integrity of sperm chromatin in young tropical composite bulls. Theriogenology 2012;78:326-33.

[31] Freneau GE, Vale Filho VR, Marques Jr AP, Maria WS. Puberdade em touros Nelore criados em pasto no Brasil: características corporais, testiculares e seminais e de índice de capacidade andrológica por pontos. Arq Bras Med Vet Zootec 2006;58:1107-15.

[32] Martí JJ, Aparicio IM, García-Herreros M. Sperm morphometric subpopulations are differentially distributed in rams with different maturity age in cryopreserved ejaculates. Theriogenology 2011;76: 97-109.

[33] Lavara R, Vicente JS, Baselga M. Genetic variation in head morphometric of rabbit sperm. Theriogenology 2013;80:313-8.

[34] Rodrigues ACN, Rocha JV, Beletti ME. Análise computacional da compactação da cromatina de espermatozoides de galo. Arq Bras Med Vet Zootec 2009;61:1302-7.

[35] Kondracki S, Bonaszewska D, Mielnicka C. The effect of age on the morphometric sperm traits of domestic pigs (Sus scrofa domestica). Cell Mol Biol Lett 2005;10:3-13.

[36] Ostermeier GC, Sargeant GA, Yandell BS, Parrish JJ. Measurement of bovine sperm nuclear shape using Fourier harmonic amplitudes. J Androl 2001;22:584-94.

[37] Parrish JJ, Schindler J, Willenburg K, Enwall L. Quantitative sperm shape analysis: what can this tell us about male fertility. Proceedings of the 24th Technical Conference on Artificial Insemination \& Reproduction 2012:74-80.

[38] Zubkova EV, Wade M, Robaire B. Changes in spermatozoal chromatin packaging and susceptibility to oxidative challenge during aging. Fertil Steril 2005;84(Suppl 2):1191-8.

[39] Fortes MRS, Satake N, Corbet DH, Corbet NJ, Burns BM, Moore SS, et al. Sperm protamine deficiency correlates with sperm DNA damage in Bos indicus bulls. Andrology 2014;2:370-8.

[40] Fatehi AN, Bevers MM, Schoevers E, Roelen BAJ, Colenbrander B, Gadella BM. DNA damage in bovine sperm does not block fertilization and early embryonic development but induces apoptosis after the first cleavages. J Androl 2006;27:176-88.

[41] Avery B, Quetglas D. Evolution of day 8 and 9 in vitro derived bovine blastocysts, fertilized with two different bulls. Theriogenology 1996;45:213.

[42] Brackett BG, Keskintepe L. Defined sperm treatments and insemination conditions enable improved bovine embryo production in vitro. Theriogenology 1996;45:259. 
[43] Kurtu JM, Ambrose JD, Rajamahendran R. Cleavage rate of bovine oocytes in-vitro is affected by bulls but not sperm concentrations. Theriogenology 1996;45:257.

[44] Larocca C, Romano JE, Calvo J, Lago I, Fila O, Roses G, et al. Relation between bulls and semen preparations on in vitro production of bovine embryos. Theriogenology $1996 ; 45: 267$.

[45] Palma G, Braun J, Stolla R, Brem G. The ability to produce embryos in vitro using semen from bulls with a low non-return rate. Theriogenology 1996;45:308.

[46] Schneider CS, Ellington JE, Wright Jr RW. Effects of bulls with different field fertility on in vitro embryo cleavage and development using sperm co-culture systems. Theriogenology 1996; $45: 262$.
[47] Carreira JT, Mingoti GZ, Rodrigues LH, Silva C, Perri SHV, Koivisto MB. Impact of proximal cytoplasmic droplets on quality traits and in-vitro embryo production efficiency of cryopreserved bull spermatozoa. Acta Vet Scand 2012;54:1-23.

[48] Silva CF, Sartorelli ES, Castilho ACS, Satrapa RA, Puelker RZ, Razza EM, et al. Effects of heat stress on development, quality and survival of Bos indicus and Bos taurus embryos produced in vitro. Theriogenology 2013;79:351-7.

[49] Benchaib M, Braun V, Lornage J, Hadj S, Salle B, Lejeune H, et al. Sperm DNA fragmentation decreases the pregnancy rate in an assisted reproductive technique. Hum Reprod 2003;18:1023-8.

[50] Beletti ME, Costa Lda F, Viana MP. A computational approach to characterization of bovine sperm chromatin alterations. Biotech Histochem 2004;79:17-23. 